\title{
ANALYSIS OF BANK-SPESIFIC FACTORS TO DETERMINE THE PROFITABILITY OF ISLAMIC BANKS IN INDONESIA : A PANEL REGRESSION APPROACH
}

\author{
Dyah Tari Nur'aini \\ Indonesia Bureau of Statistics (BPS), Kolaka, Indonesia \\ Email: dyahtarinuraini@gmail.com
}

\begin{abstract}
Analysis Of Bank-Spesific Factors To Determine The Profitability Of Islamic Banks In Indonesia : A Panel Regression Approach. Profitability is an important indicator of a bank's performance. In 2014, profits of Islamics bank in Indonesia decreased by 19.7 percent. This paper aims to analyze the impact of bank-specific factors to the Islamic banking system in Indonesia has shown better development Islamic bank's profitability. This study observed 11 Islamic banks in the Indonesia banking system in the period between 2010 - 2014. The quarterly data are taken from the Indonesian Banking Directory, published by the Financial Service Authority (OJK). Using panel data regression, the Fixed Effect Model with cross-sectional correlation (SUR) has selected as the best model. According to the obtained results, among internal factors of bank profitability, the most important one is the operating efficiency ratio. Furthermore, profitability is influenced negatively by liquidity risk, solvency risk, credit risk, and bank size.
\end{abstract}

Keywords : Bank Profitability; Islamic Banking; Panel Regression. 


\section{INTRODUCTION}

Starting from the establishment of the Indonesia's first Islamic bank namely Bank Muamalat Indonesia (BMI) in 1992 (Sari, et al, 2016), the Islamic banking system in Indonesia has shown better development and have been widely accepted in this country. Until 2014, there have been 12 Islamic banks with 2.151 units of offices in Indonesia. Therefore, in order to keep loyality of the customers, Islamic banks should increase their performance through profitability aspect. Because high profitability means good management performance of a bank (Paulin and Sudarso, 2015).

The Islamic bank's assets have continued to increase from 79.2 billion rupiahs in the fourth quarter of 2010 to 204.96 billion rupiahs in the fourth quarter 2014. Despite of an increase in assets, profits of Islamic banks actually decreased in 2014. As shown in Chart 1, Islamic bank's profit fell by 1.14 billion rupiahs throughout 2014. The decline in profit indicates a decrease in the ability of banks to optimize its assets to create profitability.

A healthy and profitable performance of bank is necessary to face negative shock in maintaining the stability. That is why the influential factors of profitability on Islamic banks in Indonesia become really important to observe. Theoretically, there are some indicators to measure bank's profitability, such as: return on assets (ROA) and return on equity (ROE). However, ROA is a major indicator that more appropriate to describe profitability, because it is focusing on the bank capability to get earning in operational activities with utilizing bank's assets (Paulin and Sudarso, 2015). It shows how bank can convert its assets to maximize its profit.

In this paper we try to identify the determinant of banks profitability and the main factors that affect the profitability of Islamic banks, over the quarterly period from 2010 to 2014. In the literature, factors that influencing bank's profitability are generally split into two groups: internal (bank-specific) factors and external (industry specific and macroecnomic) factors.

Study by Idris, et al (2011), shows that the bank-specific factors are liquidity risk, solvency risk, operating expense management, credit risk and bank size, which are characteristics of individual banks that have a direct associate to bank's management decisions and policy 


\section{Chart 1.}

The development of assets and profits of Islamic banks

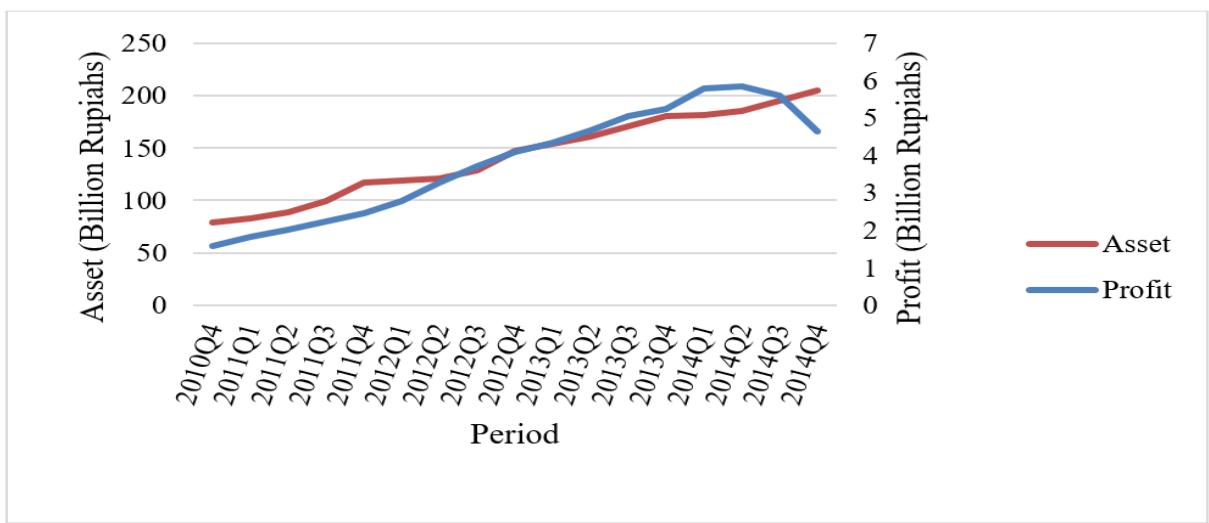

Source: The Financial Service Authority (OJK)

objectives. While external factors are economic growth, inflation, and exchange rates which are factors that are not associate with the bank's management but reflect the specifications of industrial and macroeconomic that affect financial performance. This also in line with the study by Athanasoglou, et al (2006), Idris, et al (2011), Curak, et al, et al, (2012), Teng, et al (2012), and Abduh \& Yameen (2013).

Since the bank-specific factors can be controlled by the bank's management, these factors become very important in influencing the profitability. A poor decisions in this management will cause badly on profitability. Therofore, this research focused on analysis of bank specific factors to determine the bank profitability. There are 5 hypotheses of the determinants of Islamic bank profitability, those are :

$\mathrm{H}_{1}$ : Financing to Deposit Ratio (FDR) has a significants effect to Return on Assets (ROA) in Islamic banks in Indonesia

$\mathrm{H}_{2}$ : Capital Adequancy Ratio (CAR) has a significants effect to Return on Assets (ROA) in Islamic banks in Indonesia

$\mathrm{H}_{3}$ : Operation Efficiency Ratio (OER) has a negative and significants effect to Return on Assets (ROA) in Islamic banks in Indonesia $\mathrm{H}_{4}$ : Credit Risk (NPF) has a negative and significants effect to Return on Assets (ROA) in Islamic banks in Indonesia

$\mathrm{H}_{5}$ : Bank Size (Size) has a significants effect to Return on Assets (ROA) in Islamic banks in Indonesia 


\section{METHODOLOGY}

The research covers 11 Islamic banking institusions in Indonesia that have complete financial data, such as PT Bank Muamalat, PT five independent variables (FDR, CAR, OER, BNI Syariah, PT Bank Syariah Mandiri, PT NPF, Size). Table 1 summarizes the variables Bank Mega Syariah, PT Bank Maybank Syariah used in this paper and their expected effect on Mandiri, PT Bank Victoria Syariah, PT BRI bank profitability.

Syariah, PT Bank Jabar Banten Syariah, PT

This study used panel data regression Bank Panin Syariah, PT Bank Syariah Bukopin, to analyze the determinants of profitability dan PT BCA Syariah. The data are obtained of Islamic bank in Indonesia. Panel data are from the financial report of the selected banks commonly used because of some reasons. that collected by OJK. The data are on a Based on Gujarati (2004), panel data have

Table 1.

Variables Description

\begin{tabular}{|c|c|c|c|}
\hline Variables & Symbol & Proxy & $\begin{array}{l}\text { Expected } \\
\text { Relation }\end{array}$ \\
\hline \multicolumn{4}{|l|}{ Dependent Variable } \\
\hline Return on Asset & ROA & $\begin{array}{l}\text { net profit before } \\
\text { tax/total assets. }\end{array}$ & \\
\hline \multicolumn{4}{|l|}{ Independet Variable } \\
\hline Liquidity & FDR & $\begin{array}{l}\text { financing/fund third } \\
\text { parties }\end{array}$ & $+/-$ \\
\hline Solvability & CAR & $\begin{array}{l}\text { capital/risk weighted } \\
\text { assets }\end{array}$ & $+/-$ \\
\hline $\begin{array}{c}\text { Operation Efficiency } \\
\text { Ratio }\end{array}$ & OER & cost $/$ income & - \\
\hline Credit Risk & NPF & bad debt/financing & - \\
\hline Bank Size & Size & $\begin{array}{l}\text { logarithm of total } \\
\text { assets }\end{array}$ & $+/-$ \\
\hline
\end{tabular}


advantages to give more informative data and more variablility by combining time series and cross section observations. Besides that, this technique allows to study the impact of bankspecific characteristics, with less collinearity among variables, more degree of freedom, and greater efficiency (Abduh and Yameen, 2013).

In panel data regression techniques, there are three models, such as pooled effect models, fixed effect models, and random effect models (Greene, 2007:183). Informally, random effect model can be chosen if number of cross sections greater than number of time series. Whereas, if number of cross section less than number of time series, then use fixed effect. Nevertheles, it is recommended that selection of the best model should be obtained by using formal test, such as Chow test, Hausman test, and Lagrange Multiplier (LM) test.

Then, proceed the selection of the residual variance-covariance structure to find the appropriate estimation method by using $\lambda \mathrm{LM}$ test. This test is to determine whether there is a variance-covariance structure that has cross sectional correlation or not. If the residual variance-covariance structure has a correlation between individuals, then choose cross- sectional correlation (SUR). However if there is no correlation between individuals, choose cross section weight.

In addition, to analyze the determinants of profitability, this paper also analyzes the dominant variable in influence profitability. Standardized variable can be used to obtain this objective, since it does not matter in what unit regressand and regressors are measured (Gujarati and Porter, 2008). The standardized regression coefficients, also sometimes called beta coefficients, have been proposed to facilitate comparisons between regression coefficients (Neter, 1983).

$$
\beta_{\mathrm{x}}^{*}=\beta_{\mathrm{x}}\left(\frac{\mathrm{s}_{\mathrm{x}}}{\mathrm{s}_{\mathrm{y}}}\right)
$$

\section{Descriptions :}

$\beta_{\mathrm{X}}^{*}=$ beta coefficients of the $\mathrm{X}$ regressor

$\beta_{X}=$ coefficients of the $X$ regressor

$\mathrm{S}_{\mathrm{X}}=$ standard deviation of the $\mathrm{X}$ regressor

$\mathrm{S}_{\mathrm{y}}=$ standard deviation of the regressand

This research adopt the following regression equation to study the determinants of profitability of Islamic banks in Indonesia,

$$
\begin{aligned}
\mathrm{ROA}_{\mathrm{it}}= & \alpha_{\mathrm{i}}+\beta_{1} \mathrm{FDR}_{\mathrm{it}}+\beta_{2} \mathrm{CAR}_{\mathrm{it}}+\beta_{3} \mathrm{OEM}_{\mathrm{it}} \\
& +\beta_{4} \mathrm{NPF}_{\mathrm{it}}+\beta_{5} \mathrm{Size}_{\mathrm{it}}+\varepsilon_{\mathrm{it}} \cdots \cdots \ldots \ldots \ldots \ldots \ldots \\
\text { Descriptions : } & \\
\mathrm{ROA}= & \text { Return on Assets } \\
\mathrm{FDR}= & \text { Financing Deposit Ratio } \\
\mathrm{CAR}= & \text { Capital Adequacy Ratio } \\
\mathrm{OER}= & \text { Operating Efficiency Ratio } \\
\mathrm{NPF}= & \text { Non-Performing Finance } \\
\text { Size }= & \text { Bank Size } \\
\alpha_{i}= & \text { a constan } \\
\beta_{i}= & \text { regression coeficient } \\
\varepsilon_{i t}= & \text { error term }
\end{aligned}
$$




\section{RESULT AND DISCUSSION}

The average ROA of Islamic Banks since the fourth quarter of 2010 tend to increase until the first quarter of 2013 (Chart 2.). However, there was a turning point in the second quarter of 2013 where ROA continued to decline and reached 0.68 percent in the end of 2014. The decline of ROA can not be separated from the bank's internal management which is not going well.

Declining of FDR ratio indicates a lack of funding distribution for third-party funds is fixed effect model with cross-sectional obtained, where banks tend to choose to maintain correlation (SUR). The classical assumption liquidity rather than increase profitability. test, such as normality and multicolinearity

Chart 2.

The development of FDR, CAR, OER, NPF, and ROA of Islamic banks

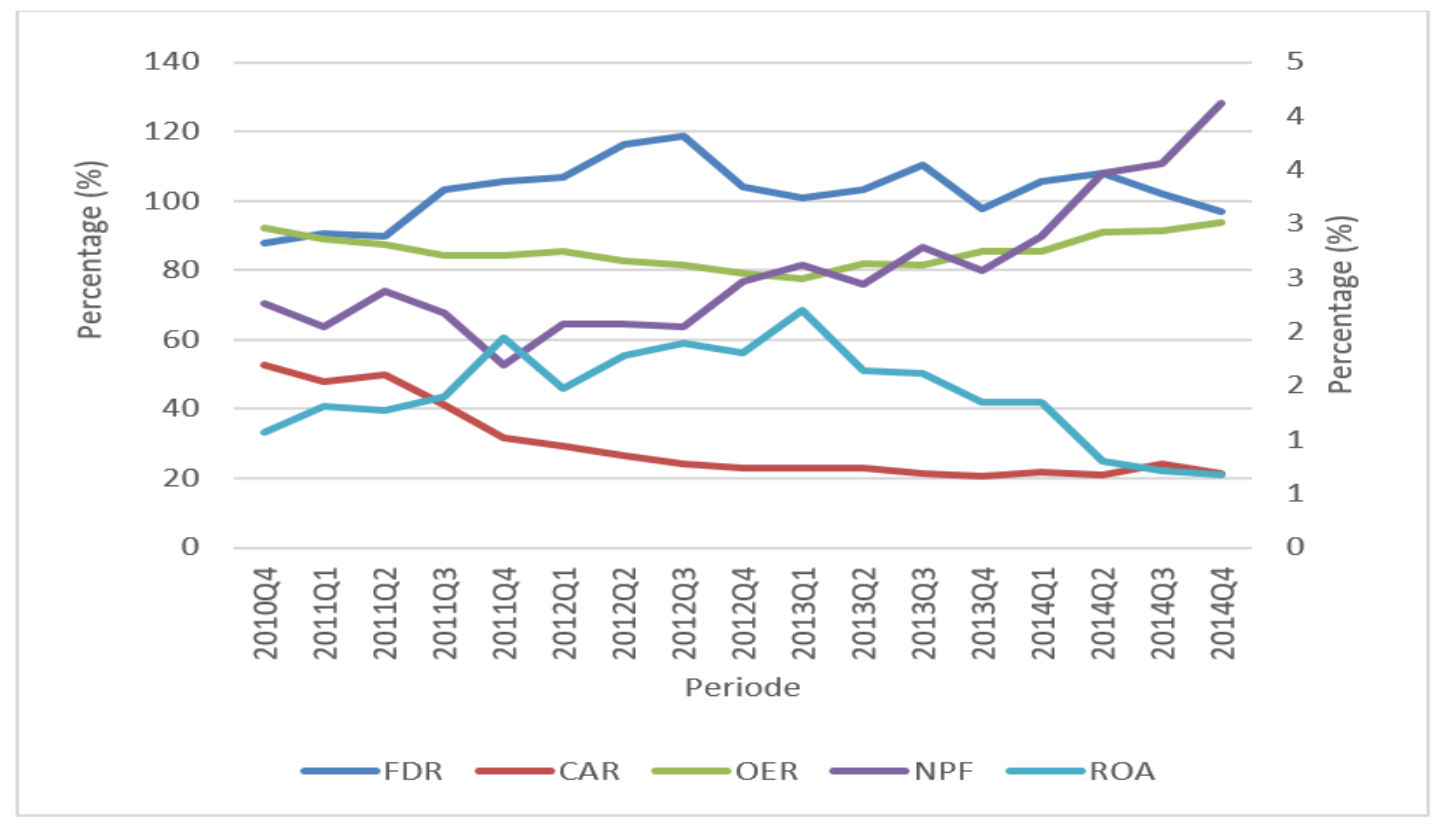


have been satisfied. The result in Table 2. reports the estimated coefficient of fixed effect model, based on the result of Hausman spesification test.

From the Table 2, the value of $\mathrm{R}$ squared is 0,9727 . This value indicates that the variations of 5 independent variables used in this study (FDR, CAR, OER, NPF, Size) could explain the variation of dependent variable (ROA) for about $97.27 \%$. Meanwhile, the remaining $2.73 \%$ is explained by other factors which are not included in the model. The probability of F-statistics is 0.000 . Since the value of significance is lower than 0.05 , it indicates that at least one of the independent variabels has significant effect to the dependent variable.

As mentioned earlier, 5 bank-spesific variables are used. According to the result obtained in this study, by judging t-test, the null hypotheses are well rejected. The absolute value of t-statistic variable of FDR, CAR, and Size, are greater than the critical value of the partial two-way test 2,2613 . Whereas, the values of t-statistic variable OER and NPF showed a smaller value than the critical value of partial one-way test $-1,9739$. That can be said that all analyzed bank spesific variables have significant influence on bank profitability.

Table 2.

\section{Estimation Results}

\begin{tabular}{ccc}
\hline Variables & Coefficient & t-Statistic \\
\hline C & 14,62235 & $32,02883^{*}$ \\
FDR & $-0,002621$ & $-3,068167^{*}$ \\
CAR & $-0,010121$ & $-7,750326^{*}$ \\
OER & $-0,061044$ & $-55,55892^{*}$ \\
NPF & $-0,084826$ & $-8,916814^{*}$ \\
SIZE & $-0,463993$ & $-19,04298^{*}$ \\
\hline R-squared & & 0,972716 \\
\hline Prob (F-statistic) & & 0,000000
\end{tabular}

*significance at the 5 percent levels

Source : Author's calculation 
From this study, it is surprisingly does not lead to an increase in profit of the revealed that all of 5 independent variable banks. Thus, although higher level of the bank show negatively impact towards the dependent capital provides safety, over caution in banking variable. Discussion in more details on the bussiness reduce the profitability (Curak, et al, relationship between independent variable and 2012). In addition, there is also an increase in dependent variable are as follow.

risky capital such as transfers of funds Hajj

This study found that liquidity, which from conventional banks, so the cost to bear used the total financing to deposits ratio as a proxy, had a significant relationship with profitability. Interestingly, negative relationship was found between FDR and ROA, which suggested that an increase in deposits do not generate more profit to the bank. This could be due to increased the bad debt, so an increase in financing can not followed by an increase in profits. Furthermore, if banks provides many financing funds, actually it is really dangerous to the bank's suistainability and increase liquidity risk (Paulin and Sudarso, 2015). This findings is similar with study reported by Alhamdita dan Heykal (2013), Anggraini (2014), dan Paulin and Sudarso (2015).

This study shows a negative relationship between solvency risk, which proxied by capital adequacy ratio (CAR), with profitability. A negative relationship between CAR and ROA suggest that an increasing among of capital even gretaer and deacrease the profitability. This results also supported by studies that have been conducted by Curak, et al (2012), Alhamdita and Heykal (2013), and Febrianto and Maskur (2015) which says that CAR has a negative effect to ROA.

Higher OER means smaller ROA. This can be due to the rising of bank operationt costs such as renew facilities and services provided (Paulin and Sudarso, 2015). When the increase in revenues is not as much as its operational cost, the profitability would be declining. The high expense can be due to the increasing in provision cost that must be provided by the banks. This result also in line with researches by Curak, et al (2012), Petria, et al (2013), and Rahaman (2015) which found that the effect of OER is significantly negative to profitability. Credit risk (NPF) also has a negative and statisticaly signficant impact on bank 
profitability. Lack of monitoring programs could also lead to the high of non-performing finance. Based on the result, it has been known tha higher non-performance finance would make profitability goes down. It happens due to the lack of monitoring programs that make the returns are not collected on time. So, it can hamper the income of operational activities. The same results are also obtained by Curak, et al (2012), Petria, et al (2013), and Rahaman (2015).

Bank size was found to be a significant but has inverse relationship with profitability. This results gives support to the recent papers from Almazari (2014), Rahaman (2015), and Havidz and Chandra (2015), who stated that there is a negative and significant effect between bank size and profitability. The reason is because the bank could not maintain the assets as they growing into bigger bank. The recent papers also mention that the diseconomies of scale occur when the level of size increase. Growing banks may face diminishing marginal returns, so the average profit could decline with size (Almazari, 2014).

The result in table 3 shows that the operating expense ratio (OER) has the greatest absolute standardized regression coefficients among other variabels. Its exhibits the very strong explanatory power of operating expense towards the level of profitability. It can be said that this variable has the most important effect on bank profitability among other variables. Thus, the banks should focus more on managing the expenses in order to improve the efficiency and increase the bank profitability (Curak, et al, 2012). It indicates that if the (standardized) OER increase by one standar deviation, on average, the (standardized) ROA decreases by about 0,72761 standar deviations.

Table 3.

Standardized Coefficient

\begin{tabular}{cc}
\hline Variable & Standardized \\
\hline FDR & $-0,08782$ \\
CAR & $-0,23183$ \\
OER & $-0,72761$ \\
NPF & $-0,11931$ \\
SIZE & $-0,50689$ \\
\hline
\end{tabular}

Source : Author's calculation 
Meanwhile, the lowest explanatory power of coefficient standardized in explaining ROA is FDR, which the result is $-0,08782$. It shows that the increasing of (standardized) FDR by ine standar deviation, on average, then only will decrease (standardized) ROA for about 0,08782. This finding also in line with the study by Havidz and Chandra (2015), which found that the weakest explanatory power of coefficient is FDR in explaining ROA.

\section{CONCLUSION AND SUGGESTION}

This paper analyzed determinants profitability of 11 Islamic banks in Indonesia in period between the fourth quarter of year 2010 and the fourth quarter of year 2014 using panel regression analysis. According to our results, the profitability of the banks is determinate by bank-spesific factors, namely liquidity risk, solvency risk, operating expense ratio, nonperforming finance, and bank size. Since the bank-spesific factors are the results of bank policies and managements, thus the banks have abilility to influence them. This study shows those independent variables have negative and significant effect to profitability, which is the return on assets (ROA). In addition, the most important bank-specific determinant of profitability is operating expense ratio (OER). Therefore, banks should undertake the activities, whether it is necessary or not, to reduce management cost in order to increase the cost efficiency.

For the next study, it recommends to add more observation unit, use more set of explanatory variables such as externalmacroeconomic variable, and analyze using longer periods of time.

\section{REFERENCE}

Abduh, M., Yameen, I. (2013). Determinants of Islamic Banking Profitability in Malaysia. Australian Journal of Basic and Applied Sciences, 7(2), 204-2010.

Akhtar, M.F., Khizer, A., Shama, S. (2011). Factors Influenching the Profitability of Islamic Banks of Pakistan. International Research Journal of Finance and Economics, 66.

Alhamdita, E.R., Heykal, M. (2013). Analisis Estimasi dan Faktor-Faktor yang Mempengaruhi Tingkat Profitablitas Bank Umum Syariah di Indonesia (Studi Kasus PT Bank Syariah Mandiri Periode 2008-2011). Binus Business Review, 4 (1), $186-196$.

Ali, A., Li, H., \& Abid, A. 2016. Efficiency and Performance of Islamic Banking in Pakistan-Stochastic Frontier Analysis. International of Economic, Finance, and Management, Vol 5(2).

Almazari, A. A. (2014). Impact of Internal Factors on Bank Profitability: Comparative Study Between Saudi Arabia and Jordan. Journal of Applied Finance \& Banking, Vol 4, (1), 125-140. 
Amelia, Erika. (2015). Financial Ratio and Its Influence to Profitability in Islamic Banks. Journal Al-Iqtishad, Vol 7, (II).

Anggraini, Mei. (2014). Analisis Pengaruh Financing to Deposits Ratio (FDR) dan Loan to Assets Ratio (LAR) Terhadap Profitabilitas Perbankan Syariah di Indonesia [Thesis]. Surakarta : Universitas Muhammadiyah Surakarta

Athanasoglou, P. P., Sophocles, N.B., \& Matthaios, D.D. (2006). Determinants of Bank Profitability in The South Eastern European Region. Economic Research Department.

Baltagi, B.H. (2005). Econometric Analysis of Panel Data (ed). England: John Wiley \& Sons

Bashir, A.H.M. (2001). Assesing the Performance of Islamic Banks : Some Evidence from the Middle East. Journal of Bussines, 3.

Curak, M., Klime, P. \& Sandra, P. (2012). Profitability Determinants of the Macedonian Banking Sector in Changing Environment. Procedia - Social and Behavioral Sciences (44) : 406- 416.

Febrianto, F., Ali, M. (2015). Analisis Pengaruh CAR, FDR, NPF, BOPO terhadap Profitabilitas Bank Syariah (ROA). Journal of Accounting and Banking, 4(2).

Ferrouhi, E. M., Agdal, M. V. dkk. (2014). Liquidity and Solvency in the International Banking Regulation. The Clute Institute International Academy Conference.

Greene, W.H. (2003). Econometric Analysis (ed). England: Pearson Education

Gujarati, D.N. (2004). Basic Econometric (ed). New York : McGraw-Hill

Gujarati, D.N., Dawn, C.P. (2004). Basic Econometric (ed). New York : McGraw-HillHavidz,

H., Chandra, S. (2015). The Determinants of ROA of Full-Fledged Islamic Banks in Indonesia. Journal MIX, Vol 5, (I), 161175.

Haron, S. (2004). Determinants of Islamic Bank Profitability. Global Journal of Finance and Economics, 1(1).

Havidz, H. dkk. (2015). The Determinants of ROA of Full-Fledged Islamic Banks in Indonesia. Journal MIX, Vol 5, (I), 161175.

Idris, A.R., Fadli, F.A.H.A., \& Noor, A.A.F. (2011). Determinan of Islamic Banking Institutions Profitability in Malaysia. World Applied Sciences Journal 12, 01(07).

Lall, Pooran. (2014). Factors affecting U.S. Banking Performance : Evidance Frm the 2007-2013 Financial Crisis. International Journal of Economics, Finance, and Management, Vol 3(6).

Neter, J., et al. 1983. Applied Linear Regression Models. Illinois : USA

Paulin, O., Sudarso, K.W. (2015). Determinants of Islamic Bank's Profitability in Indonesia for 2009-2013. Journal of Business and Management, 4(1), 175-185.

Petria, N., Bogdan, C., Iulian, I. (2015). Determinants of Banks's Profitability : Evidence from EU 27 Banking Systems. Procedia-Economics and Finance (20) : $518-524$.

Rachdi, H. (2013). What Determines the Profitability of Banks During and before the International Financial Crisis? Evidence from Tunisia. International Journal of Economics, Finance, and Management, Vol 2(4).

Rahaman, M. M., dan Sharmin, A. (2015). Bank- Specific Factors Influencing Profitability of Islamic Banks in Bangladesh. Journal of Business and Technology, Vol 10, (I).

Setyawati, I., et al. (2015). Assesing the Islamic Financial Performance in Indonesia. International Journal of Education and Research, 3(10).

Sari, M. D., Zakaria, B., Zahri, H. 2016. History of Islamic Bank in Indonesia: Issues Behind Its Establishment. International Journal of Finance and Banking Research, 2(5): 178-184

Teng, K. Y., et al. (2012). The Determinnats of 
Islamic Banks Profitability in Malaysia. A Research Project of Business Administration Banking and Finance. Malaysia : Universiti Tunku Abdul Rahman

Umam, Khaerul. (2013). Manajemen Perbankan Syariah. Bandung : Pustaka S 